This paper gives examples of the implementation of energy-saving measures in public premises. The introduction of energy-saving measures at enterprises significantly reduces the fixed component of industrial expenditures.

As a rule, educational institutions, for example, public premises, are financed from the state budget, and saving money on utilities will enable redirecting finances to the development of the university's educational and scientific base.

Thus, the main purpose of implementing such measures is to reduce the cost of maintaining buildings.

The measures are divided into three stages. At the first preparatory stage, the problem elements of a building and communications, which require the introduction of energy-saving measures using a special Fluke Ti25 device, are identified. Problem elements of the building structure were determined by complete scanning of the ceiling, walls, and floor with the help of a thermal imager. A large (more than $10 \%$ ) difference between indoor air temperature and the temperature of the building element indicates a problem element. The research method is thermographic.

The study contains an example of scanning the wall of the premises. The temperature difference between the left and the right sides of the wall is $2.6{ }^{\circ} \mathrm{C}$ (the difference with the room temperature is $21 \%)$. This indicates significant heat losses through the wall. At the second stage of information processing, measures to reduce energy consumption were determined. At the third stage of the introduction of energy-saving measures, the measures that directly affect the energy consumption of a building and effective functioning of communications were implemented.

The practical relevance of the study is to obtain results and practical recommendations that can be applied in practice to improve the energy efficiency of premises and buildings

Keywords: energy saving in premises, energy audit of buildings, energy sources, energy-saving measures, technological measures, investment measures

\section{DETERMINING HEAT LOSSES IN UNIVERSITY EDUCATIONAL PREMISES AND DEVELOPING AN ALGORITHM FOR IMPLEMENTING ENERGY- SAVING MEASURES}

\section{Marina Savchenko-Pererva}

Corresponding author

$\mathrm{PhD}$, Associate Professor

Department of Technology of Nutrition**

E-mail: marina.saw4encko2011@gmail.com

O leg Radch u k

$\mathrm{PhD}$, Associate Professor

Department of Engineering Systems Design**

L u d mila Rozhkova

$\mathrm{PhD}$, Associate Professor Department of Philosophy and Socio-Humanities**

Hanna Barsukova

PhD, Senior Lecturer*

O leksandr Savoiskyi Senior Lecturer*

*Department of Energy and Electrical Engineering Systems** **Sumy National Agrarian University Herasyma Kondratieva str., 160,

Sumy, Ukraine, 40000
Received date 22.10.2021 Accepted date 30.11.2021 Published date 24.12.2021
How to Cite: Savchenko-Pererva, M., Radchuk, O., Rozhkova, L., Barsukova, H., Savoiskyi, O. (2021). Determining heat losses in university educational premises and developing an algorithm for implementing energy-saving measures. Eastern-European Journal of Enterprise Technologies, 6 (8 (114)), 48-59. doi: https://doi.org/10.15587/1729-4061.2021.245794

\section{Introduction}

Unstable pricing policy in the provision of energy resources leads to the actualization of the issue of energy-effective use of thermal energy. The introduction of energy-saving measures is the main direction of reducing the cost of maintaining premises and buildings [1,2]. In order to enhance the energy efficiency, many enterprises conduct an energy audit, through which the real situation with energy supply and the energy consumption is determined [3, 4]. The use of the method for minimizing the energy consumption process becomes quite relevant $[5,6]$. This is done by calculating the justified volumes of energy consumption and approaching them by optimizing heat transfer between processes, methods of energy supply and improving the characteristics of technological processes [7, 8]. This method is called pinch analysis or integration of processes [9]. The issue of the development and improvement of methodological and technical foundations for energy-saving measures is also relevant [1].

Energy efficiency and energy saving are key concepts of ensuring the efficiency of both businesses and the state in general [10]. Energy-saving is a complex of organizational, legal, industrial, scientific, economic, technical, and other 
measures aimed at the rational use and economical consumption of fuel and energy resources [11]. Energy intensity of production is the magnitude of energy and fuel consumption for the main and auxiliary technological processes of production in the field of agro-industrial complex $[12,13]$, the performance of operations, provision of services based on the given technological system [14, 15]. Energy efficiency is one of the main strategic directions of the development of the budget industry [16, 17], a necessary tool for achieving comfortable conditions in the buildings of educational institutions, healthcare, children's, and public institutions [18, 19]. The main purpose of these events is to implement the standards of living of the modern European community [20,21].

Efficient use of energy is one of the integrated indicators of the development of the economy, science, and socio-cultural development of the nation [22]. According to this indicator, the countries of Eastern Europe are among those countries where the stagnation of the existing provision can provoke a serious economic crisis with subsequent large-scale social shocks. In terms of energy efficiency, the situation in the housing and communal complex remains the most complicated [23, 24]. Worn-out heat and water supply stations operate at low efficiency and supply heat through the same worn-out networks. As a result, energy losses reach $45-50 \%$ [25].

The main task of today when it comes to energy saving is the need to ensure the efficient and rational use of fuel and energy resources (FER) in all industries in Eastern Europe. These countries are energy-deficient states that import $75 \%$ of natural gas and $85 \%$ of oil and petroleum products. This structure of the fuel and energy balance is critical and unacceptable in terms of energy security. Based on this, one of the main tasks of the countries is to significantly reduce the inefficient consumption of energy resources. This task cannot be solved without a targeted energy policy, which would take into consideration the country's capabilities for its hydrocarbon production, development of renewable energy and energy saving, a transition of the economy to the introduction of innovations in production. At the same time, phased and consistent energy-saving measures can save up to $1 / 3$ of energy resources [16]. The issues of energy audit and energy management for the formation of measures to improve the energy efficiency of energy supply systems are relevant.

\section{Literature review and problem statement}

The authors of $[9,14,17]$ considered a significant number of types of energy-saving measures.

Article [9] proposed organizational measures that include internal energy audit, drawing up the energy passport of an enterprise, development of energy-saving measures, and improvement of efficiency of technological processes. These measures also include monitoring of the implementation of the accepted measures to stimulate and motivate energy-saving behavior, the introduction of the right to dispose of funds from energy savings, and the establishment of rules for purchasing the equipment for energy-efficient technologies. However, organizational measures are measures of a quick return and sometimes do not bring the desired result.

The authors of paper [14] explored the technological measures that are more radical and contribute to the rapid implementation of cost-effective and financially attractive investments. They provide for the introduction of energy efficiency standards in the area of using industrial buildings, industrial equipment, the introduction of circulating water supply systems, window cleaning, painting the walls of premises with light paint. These measures also include the application of used-up heat of refrigerators and air conditioners for heating water, introduction of the systems that provide an increase in the efficiency of electric motors in facilities with an alternating load. In addition, financial support from banks and leasing companies may be required to implement energy-efficient projects.

Paper [17] proposed the investment measures that contribute to eliminating the main causes of low energy efficiency and in most cases guarantee more significant energy savings. First of all, it is the transition to alternative sources of energy supply and the use of modern energy-saving production technologies. Although the measures of this group are most effective, they require higher initial costs. In addition, organizational changes at the country and region level are of great importance for the implementation of these measures. These include pricing reform, improvement of electricity and gas markets, transition to integrated planning of various energy sources.

Paper [26] provides the results of research into the analysis of inefficient use of the FER and identifies the ways, means, and methods for their economic use. The reason for this may be objective difficulties associated with the continuous and rapid increase in the cost of the FER, which motivates to find ways to reduce their use.

One of these ways is the reduction of energy consumption by production equipment. One of the most energy-efficient production processes in the processing industry is drying. Article [27] proposes a method for improving the equipment for intensification of the drying process of dispersed food products. It was established that due to the effective use of the volume of a drying chamber and an increase in the surface of the phase contact, the drying process became more intensive, and the cost of the dried product decreased. The authors of paper [28] proposed a combined method for drying fruit and vegetable raw materials using direct electric heating. It was found that the developed method leads to the intensification of the process and a significant decrease in its energy intensity while ensuring the established quality of the finished products. In both cases, a significant reduction in energy consumption was proved, however, very often the improvement of drying technology entails a complication of the production process and a significant increase in the cost of drying equipment.

Another option to reduce FER consumption is to conduct an energy audit on energy efficiency and energy saving.

According to [29, 30], an energy audit is a systematized analysis of use and consumption of energy for determining, quantitative expression, and preparation of the report on the possibility of the improvement of energy efficiency.

The objectives of energy audit of buildings according to [31] are:

- determining the general state of the facility consuming the FER, its main subdivisions, and technological processes as FER consumers;

- analysis of balances of FER consumption separately for each type;

- analysis of balances of FER consumption in energy-intensive technological plants, technological processes, and subdivisions;

- analysis of the FER losses in facilities;

- analysis of the cost of the FER in the cost of production; 
- assessment of the potential of energy saving of facilities;

- assessment of the efficiency level of using the FER;

- analysis of specific consumption of the FER and comparison with current norms and standards, preparation of proposals for its reduction;

- assessment of the effectiveness of the ESM functioning;

- development of recommendations for the implementation of energy-saving measures with their technical and economic assessment.

Comprehensive approaches to the examination of structures during energy audit include assessment of [32]:

- the microclimate of premises;

- state of enclosures;

- state of engineering systems of heating, ventilation, and air conditioning;

- fire safety of a building;

- heat-energy state of a building.

The authors of paper [33] provide analytical recommendations that can be used as a template by engineers-practitioners to assess energy use at production facilities and implement certain energy-saving measures. Studies [34,35] assessed and analyzed energy consumption and implemented a number of energy-saving measures for historic buildings. The proposed measures significantly reduced energy losses, but the options for reducing energy consumption in public premises were studied insufficiently. In addition, their maximum effectiveness was not proved. That is why it is an urgent need to conduct an energy audit on energy efficiency and energy saving in public areas and maximize the reduction of energy and heat losses.

Papers [36,37] address the issue of the lack of energy resources based on new approaches, using renewable and secondary energy sources. However, the efficiency of using renewable energy sources largely depends on climatic features that make it difficult to use solar and wind energy or other natural phenomena.

The author of research [38] formed approaches to the implementation of energy-saving measures both at enterprises and housing and communal complexes. However, to select a specific group of energy-saving measures, it is necessary to identify and study the sources of energy losses in each case.

The sources analyzed above show that significant changes in the energy development strategy are taking place in the world. The advanced countries of the world identified a set of tasks for building energy strategies in the $21^{\text {st }}$ century. The main direction of development is to adhere to the inseparability and coherence of actions at ensuring three components. The first is energy supply (uninterrupted supply of electricity of appropriate quality), the second - energy availability (energy efficiency and affordable electricity price), the third - energy efficiency (minimal impact on the environment). These components are considered as the basis for achieving the global goal of ensuring sustainable development, which guarantees sustainable economic growth, living standards of the population, environmental protection.

Thus, improvement of energy efficiency of industrial production and reduction of energy consumption in residential areas of Eastern Europe is not a problem of economic feasibility, but rather a problem of survival. If countries have their own sufficient hydrocarbon reserves, energy-consuming production and significant costs in residential buildings can be decreased due to cheaper hydrocarbon prices. However, energy-consuming management methods are unacceptable, as the oil and gas industries do not receive the funds necessary for their sustainable development and begin to decline.
All this suggests that it is advisable to conduct a study on the implementation of energy-saving measures for buildings.

\section{The aim and objectives of the study}

The aim of the research is to determine the places of significant heat losses in public premises by the thermographic method and to develop an algorithm for the examination of the entire building, which will make it possible to increase the efficiency of implementation of energy-saving measures.

To accomplish the aim, the following tasks have been set:

- to study heat losses through the windows of a building;

- to study heat loss through the walls and the doors of a building;

- to study heat losses through ceilings, floors, and the heating system;

- based on the conducted thermal image scanning of external structures of premises. to develop an algorithm for the implementation of energy-saving measures.

\section{Materials and methods of research}

Today, the most effective way to find out the causes and sources of heat loss and hidden defects in a building is thermal imaging examination.

Thermal imaging examination is the registration of radiation of an object in the infrared range and conversion of a thermal image into a visible one [39]. This makes it possible to check the quality of joints of panels and seams, window and door openings, and other structures of buildings and facilities. Thermal imaging examination of a building was carried out according to the procedure given in $[39,40]$.

The research was carried out in the educational premises of the university building as an example of public premises with an area of 5 thousand square meters, where there is a large number of rooms. As a rule, the physical location of educational institutions takes place in buildings that have not been used for 30 years or more and where energy-saving technologies have not been applied.

The research procedure was as follows. Immediately before the test, the temperature of the internal and external air was measured. The enclosures were examined in the absence of direct sunlight. Thermal imaging measurements were carried out at temperature changes between the outside and inner air of at least $10-15^{\circ} \mathrm{C}$. Thermal imaging was made sequentially in predetermined areas with a frame-by-frame recording of thermograms and simultaneous photography of these areas.

As a result of fixation, a photo of the room element and a thermal image of the surface temperature and air temperature in the room were obtained. The device fixed the lowest, average, and the highest temperature of the studied surface with the markets and automatically recorded numeric values in ${ }^{\circ} \mathrm{C}$. The results obtained by the device were subjected to expert analysis to determine the places with the largest heat losses. Previously, we set the boundary minimum level of heat losses, above which it is necessary to perform heat-saving measures. In the conducted study, this level was 10 percent or more of the difference between the temperature of the element of the building and the average temperature in the room. The choice of percent depends on the financial capacity of an enterprise. The lower this indicator, the more energy-saving measures will be needed to take, the more money 
it will be necessary to spend. Such places were additionally studied by an expert, and recommendations for construction workers were developed to reduce the energy consumption of the building. All procedures for conducting an energy audit of premises were presented in the form of an algorithm that makes it possible to group energy-saving measures for elements of a building (windows, walls, ceiling, floor, doors). The calculation method for determining energy saving in quantitative and cost form was proposed.

Based on the third main stage of energy audit, the stage of obtaining information as the main stage, which involves indepth learning of the object of energy audit, documentation on the use of the FER, measurements were carried out at the energy audit object - educational premises. Measurements were performed with the use of the certified thermal imager Fluke Ti25 (serial number Ti 25-09070166) (USA) with a measurement error of $2 \%$ and thermal sensitivity of $\leq 0.1{ }^{\circ} \mathrm{C}$. During the examination, the air temperature outside was $+9^{\circ} \mathrm{C}$. The educational premises have central water heating. According to the examination results, the device captures a light image of a research object and a thermal image, which marks the surface temperature in different colors. The highest temperature and the lowest temperature of the object examined by the device are indicated as a marker with a digital value of absolute temperature. A graph of colors and corresponding temperatures is also added. The examination of a building is presented by groups of research objects: windows, walls, doors, heating system, and other elements.

\section{Results of the study of heat losses in premises}

5. 1. Studies of heat losses of windows in a building

A building is examined by studying sequentially all premises by their complete scanning. The elements of a building, which have large heat losses, the level of which is indicated in the section of the article about materials and methods, are subject to additional analysis and belong to a certain group (windows, walls, roof, floor, doors, and heating system).

Fig. 1 shows the typical results of the examination of the windows of the premises. The causes of heat energy losses were analyzed and measures to reduce them were proposed. Characteristic places with a temperature difference of different parts of a window indicate that there are heat losses.

The thermographic image IR004341. IS2 of windows No. 1 in Fig. $1, a, b$ shows that the maximum wall temperature inside the room is $20.3^{\circ} \mathrm{C}$. Analyzing examination thermogram IR004341.IS2 in Fig. 1, $a$, we determine that the temperature at the junction of the window to the wall is $16.5^{\circ} \mathrm{C}$, on the glass surface, it is $17.8{ }^{\circ} \mathrm{C}$.

According to [41], the sanitary and hygienic requirements allow the difference between the temperature of the internal air and reduced temperature of the inner surface of the enclosure: for walls $-4{ }^{\circ} \mathrm{C}$, ceiling $-3{ }^{\circ} \mathrm{C}$, floor $-2{ }^{\circ} \mathrm{C}$.

The temperature difference is $12-28 \%$. Such temperature difference indicates that the compaction between the window and the wall does not retain warmth and neither do double-glazed windows. That is why to reduce the energy losses of heat, it is necessary for builders to replace the compaction and replace the double-glazed windows.

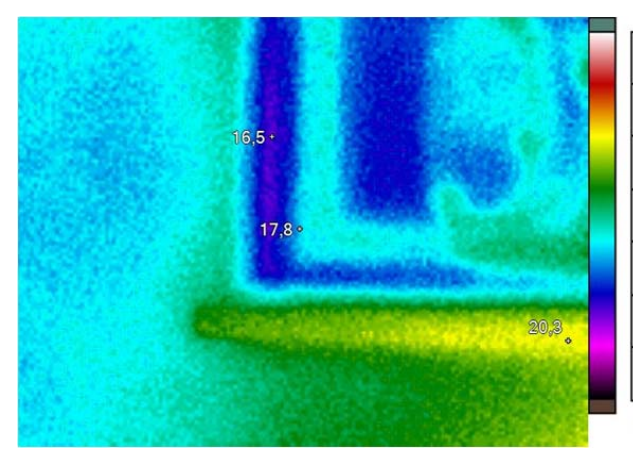

$a$

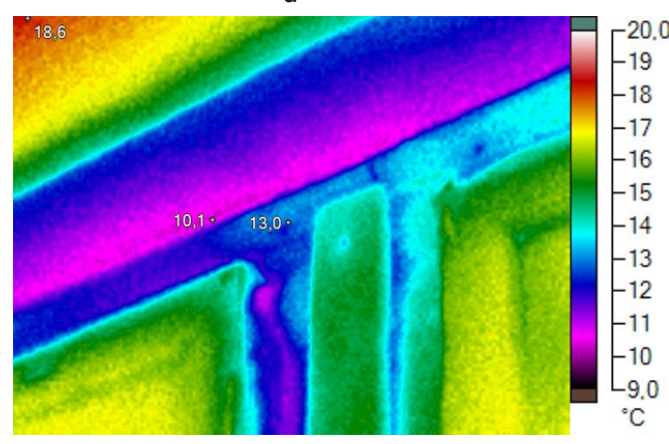

c

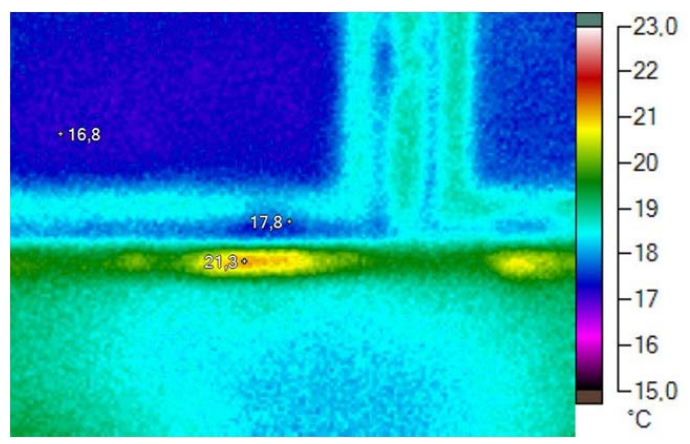

e

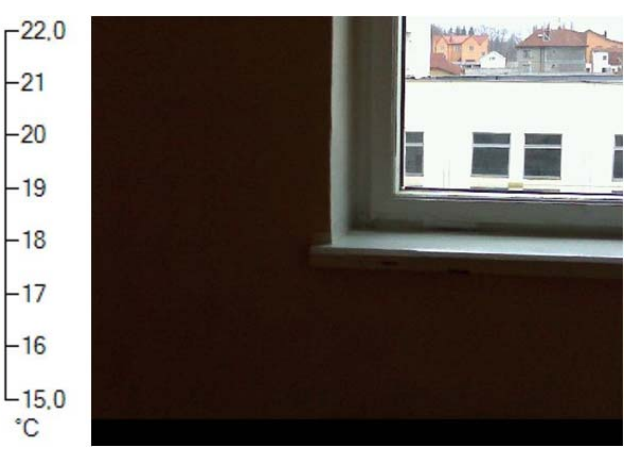

$b$

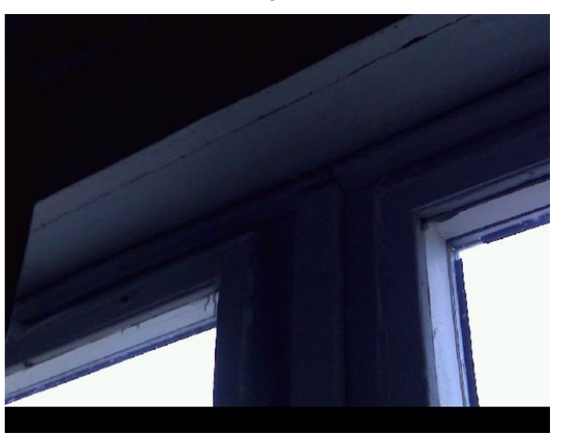

d

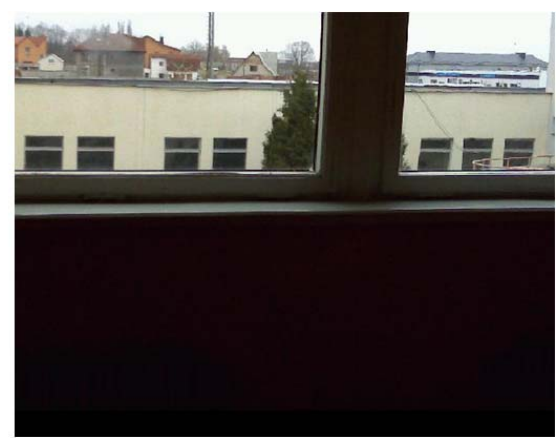

$f$
Fig. 1. Results of examination of windows in the premises using the thermal imager: $a$ - thermogram of window No. 1 IR004341.IS2; $b$ - the visible light image of a window No. 1; $c$ - thermogram of window No. 2 and the ceiling IR004367.IS2; $d$ - visiblelight image of window No. 2 and the ceiling; $e-$ thermogram of window No. 3 IR004342.IS2; $f-$ visible-light image of window No. 3 
In thermographic image IR004367.IS2 of window number No. 2 in Fig. $1, c, d$ wall temperature is $18.6^{\circ} \mathrm{C}$, the temperature of the ceiling at the junction of the window and wall is $10.1{ }^{\circ} \mathrm{C}$, which is $56 \%$ lower than the air temperature in the premises. Such a large temperature difference indicates window subsidence and the formation of a gap between the top of the window and the wall. That is why to reduce the heat energy losses, it is necessary for construction workers to make compaction of the junction of the window to the wall.

In thermographic image IR004342.IS2 of windows No. 3, Fig. 1, $e, f$, the maximum wall temperature in the room is $21.3{ }^{\circ} \mathrm{C}$. The temperature of the double-glazed window is $16.8{ }^{\circ} \mathrm{C}$, the temperature at the junction of the double-glazed window to the frame is $17.8^{\circ} \mathrm{C}$. The temperature difference is $7-27 \%$. Such temperature difference indicates that the double-glazed window is not compacted and does not keep warmth, the compaction between the double-glazed window and the frame does not fit completely. That is why to reduce heat energy losses, it is necessary to replace the double-glazed windows and replace the compaction.

\section{2. The studies of heat losses of walls and doors of} a building

Fig. 2 shows the results of the examination of the walls of the premises of a building. The air temperature in rooms 1 and 2 is $22.5^{\circ} \mathrm{C}$. Thermogram IR004358.IS2 of the walls of premises 1 in Fig. 2, $a, b$ shows that the maximum wall temperature of room 1 is $20.5^{\circ} \mathrm{C}$.

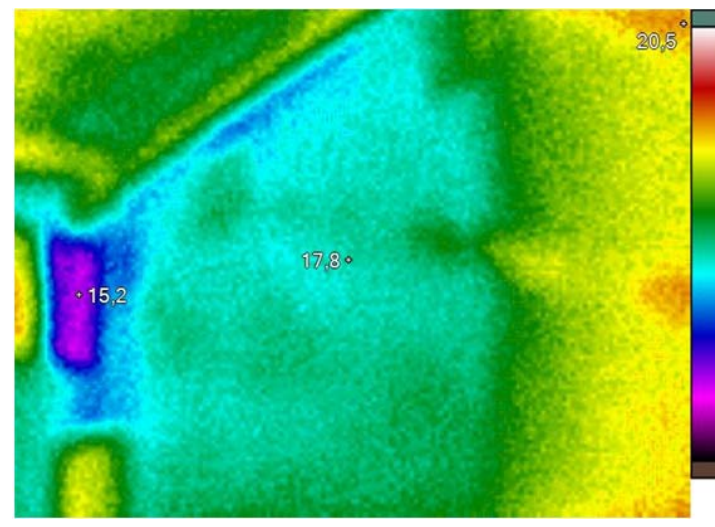

$a$

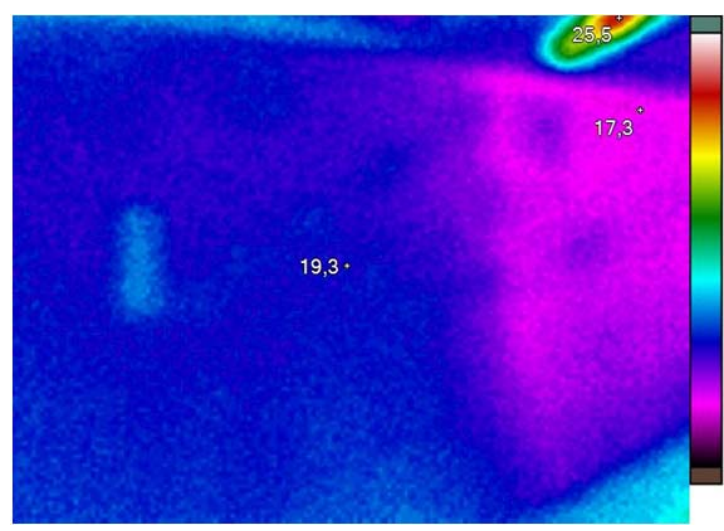

Analyzing thermographic image IR004358.IS2 made by device Fluke Ti25 (Fig. 2, a), it possible to determine two zones with much lower temperatures. The first zone has a temperature of $17.8^{\circ} \mathrm{C}$, where the temperature difference is $21 \%$, the second zone has a temperature of $15.2{ }^{\circ} \mathrm{C}$, where the temperature difference is $32 \%$ relative to the air temperature in the room.

A similar zone of sharp separation of temperature difference can be determined by thermal image IR004361.IS2 of wall 2 in the room in Fig. 2, $c, d$. The temperature difference can be determined from $19.3{ }^{\circ} \mathrm{C}$ to $17.3^{\circ} \mathrm{C}$, the difference is $10 \%$. Additional analysis of the structure of the building in places of temperature drop made it possible to determine the causes of heat losses. Thus, the element of the building, which is shown in Fig. $2, a, b$ has a temperature of $15.2{ }^{\circ} \mathrm{C}$, has a leakage of moisture from the roof of the room, and, accordingly, this element has a tendency to freezing and excessive cooling. That is why to reduce heat energy losses, it is necessary to eliminate the causes of the leakage of external moisture from the roof of the room. Analysis of the structure of the building in areas of temperature difference up to $17.3^{\circ} \mathrm{C}$ and up to $15.2{ }^{\circ} \mathrm{C}$ according to Fig. $2, a, b$ during additional examinations indicated that part of the wall of room 2 is shared with other premises outside. That is, this part of the wall is not an external element of the building, and the second part of the wall is an external element of the building. The part that is the external element of the building has losses of thermal energy, according to Fig. $2, a, b-13 \%$, according to Fig. $2, c, d-10 \%$. That is why to reduce heat energy losses, it is necessary to perform external wall insulation.
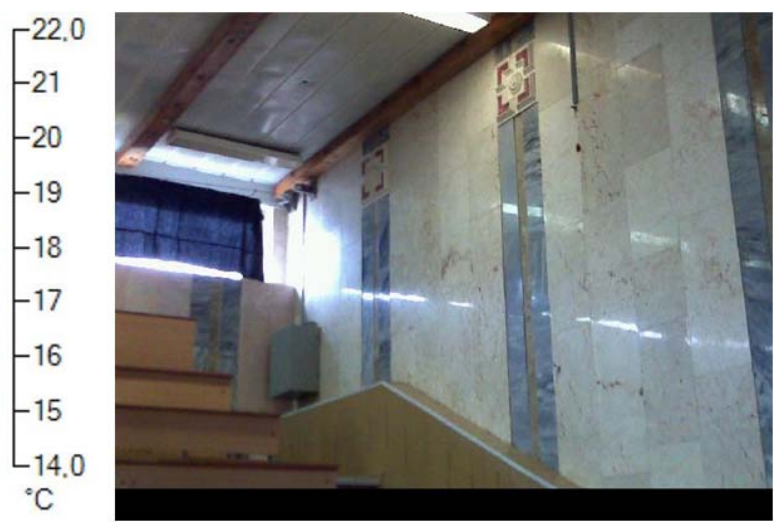

$b$

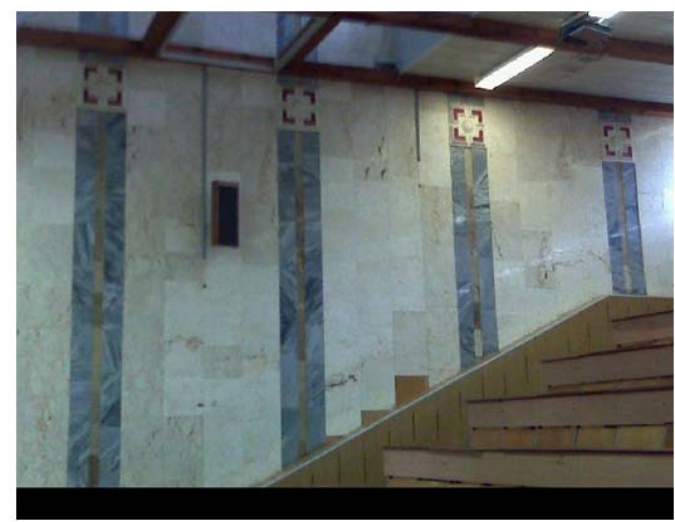

$d$

Fig. 2. Results of the examination of the walls of premises with the help of a thermal imager: $a$ - thermogram of the wall of premises 1 IR004358.IS2; $b$ - visible-light image of the wall of premises 1 ; $c$ - thermogram of the wall of premises 2 IR004361.IS2; $d$ - visible-light image of the wall of premises 2 
Fig. 3 shows the result of the examination of the external doors of premises No. 1, which are used for the passage of people.

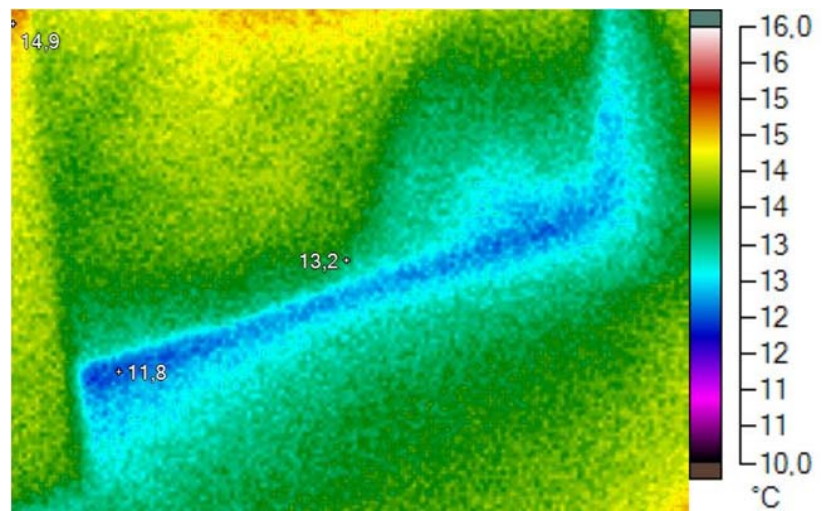

$a$

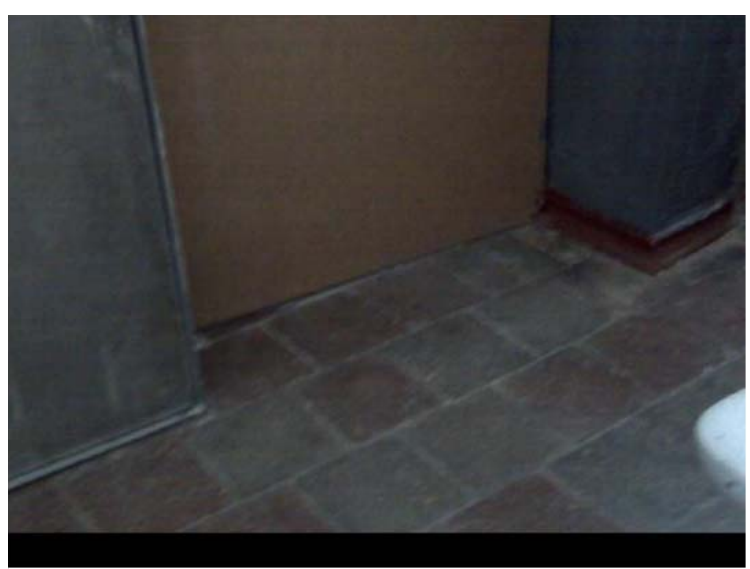

$b$

Fig. 3. Results of the examination of the external doors of premises No. 1 with the help of a thermal imager: $a$ - thermogram of doors IR004500.IS2; $b-$ the visible image of the door

Analyzing thermographic image IR004500.IS2 of device Fluke Ti25 (Fig. 3), one can determine the area at the lower part of the door, which has a temperature of $11.8^{\circ} \mathrm{C}$, which is $31 \%$ lower than the temperature in the premises, which is $16{ }^{\circ} \mathrm{C}$. Analysis of the structure of the door and the door frame in the temperature difference zone indicated that the compaction was not in order. That is why to reduce heat energy losses, it is necessary to replace the compaction at the bottom of the door.

Fig. 4 shows the results of the examination of external doors No. 2 of the premises used for the passage of automobiles.

Analyzing thermographic image IR004491.IS2, it is possible to determine the zone with a temperature of $12.1{ }^{\circ} \mathrm{C}$, which is $21 \%$ lower than the room temperature, which is $15.5^{\circ} \mathrm{C}$. Analysis of the door structure indicated that the upper compaction between the door and the door frame had failed. That is why to reduce heat energy losses, it is necessary to replace the upper door compaction.

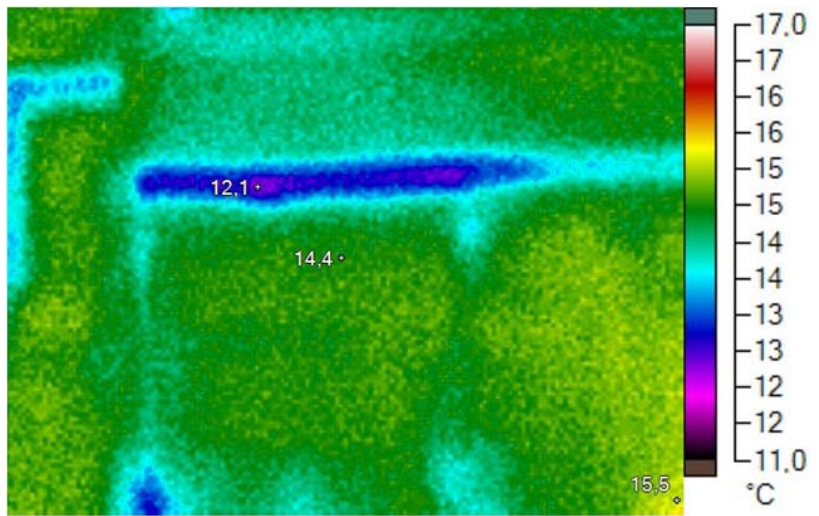

$a$

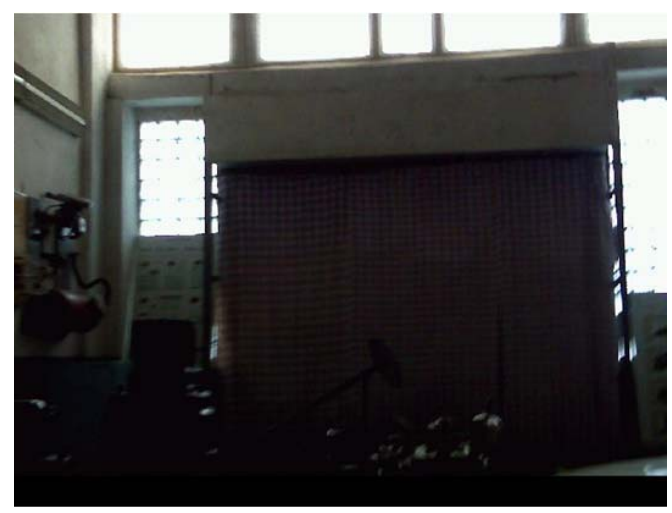

$b$

Fig. 4. The results of an examination of external door No. 2 of the premises by a thermal imager: $a$ - thermogram of doors IR004491.IS2; $b$ - the visible image of the door

5. 3. Studies of heat thermal losses of the ceiling, floor, and heating systems

Fig. 5, 6 show the results of the examination of the ceiling of the premises.

Characteristic places of a decrease in the temperature of the ceiling surface, according to thermogram IR004487.IS2 are shown in Fig. 5, with a temperature of $12.1^{\circ} \mathrm{C}$, which is $23 \%$ lower than the temperature in premises 1 , which is equal to $15.7^{\circ} \mathrm{C}$. The problem zones of the ceiling, according to thermogram IR004498.IS2, shown in Fig. 6, have a temperature of $14.0^{\circ} \mathrm{C}$, which is $22.6 \%$ lower than the temperature in the premises that is equal to $18.1^{\circ} \mathrm{C}$.

Additional analysis of the structure of the roof above these problem places of the ceiling of the premises indicated moisture leakage through the roof covering. That is why to reduce heat energy losses, it is necessary to repair the roof covering over the premises.

Fig. 7 shows the results of the examination of the floor of the premises of the building.

Analysis of thermography image IR004422.IS2 of the device Fluke Ti25 indicates a decrease in temperature on the floor stairs to $16.3{ }^{\circ} \mathrm{C}$, which is $18.5 \%$ lower than the temperature in the premises, which is equal to $20{ }^{\circ} \mathrm{C}$.

Such a sharp temperature difference indicates heat energy losses from the premises to the non-heated basement. That is why to reduce heat losses, it is necessary to insulate the floor outside in the basement. 


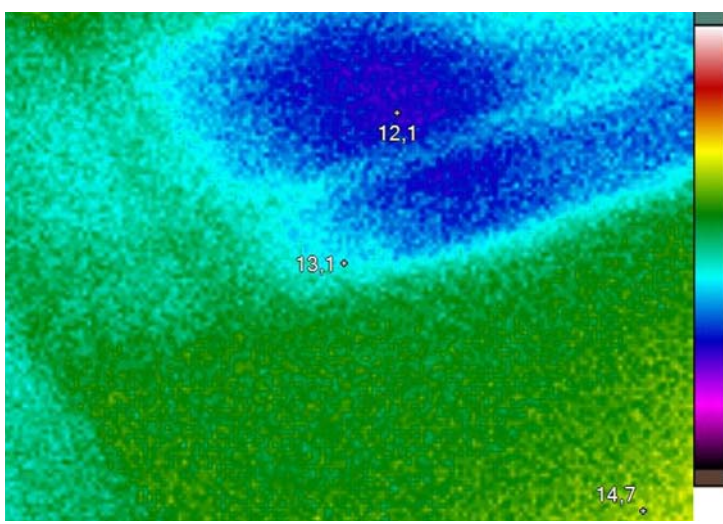

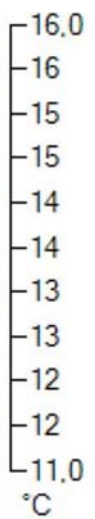

${ }^{\circ} \mathrm{C}$

Fig. 5. Results of examination of the ceiling of premises 1 with thermal imager: $a$ - thermogram of the ceiling of premises 1 IR004487.IS2; $b$ - visible-light image of premises 1

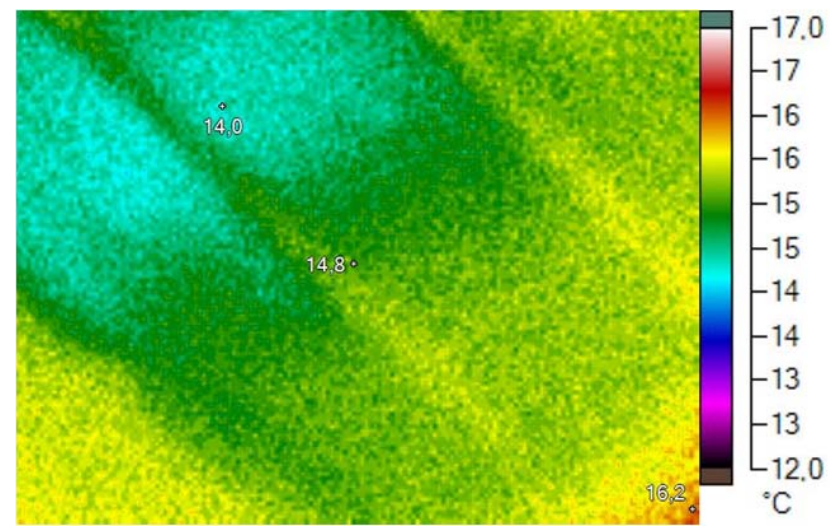

$a$

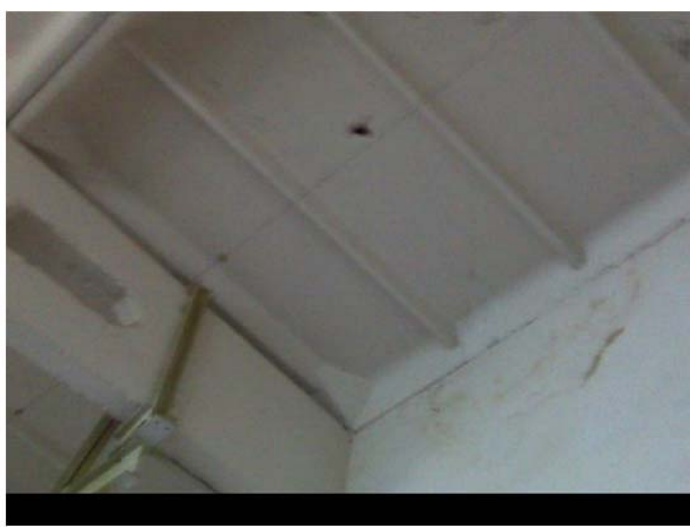

$b$

Fig. 6. Results of examination of the ceiling of premises 2 by the thermal imager: $a$ - thermogram of the ceiling of premises 2 IR004498.IS2; $b$ - visible-light image of the ceiling of premises 2

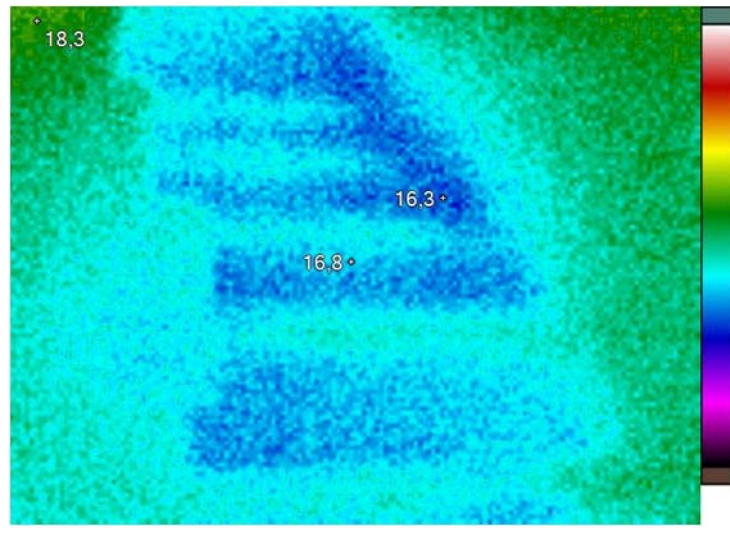

a

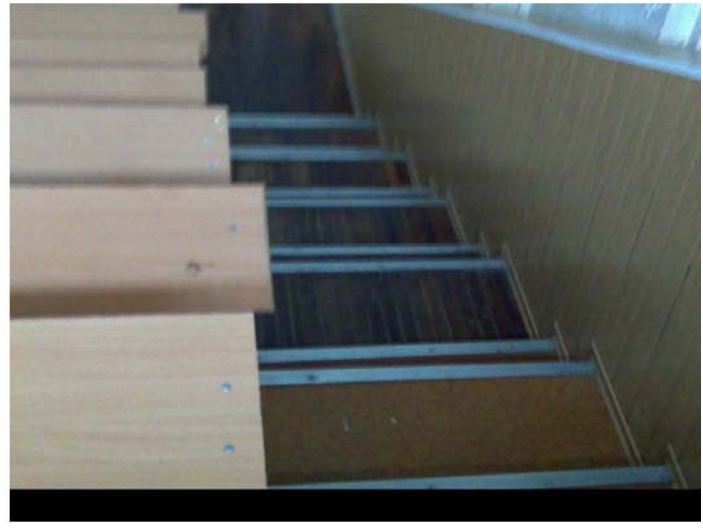

$b$

Fig. 7. Results of the examination of the floor of the premises with a thermal imager: $a-$ a thermogram of the floor of the premises IR004422.IS2; $b$ - the visible light image of the floor of the premises

Fig. 8 shows an example of the result of the examination of the elements of the heating system, namely, the radiator. Analysis of thermographic image IR004443.IS2 of device
Fluke Ti25 indicates that the coolant distribution occurs from the bottom right side in two sections, and then from the top of the radiator. 


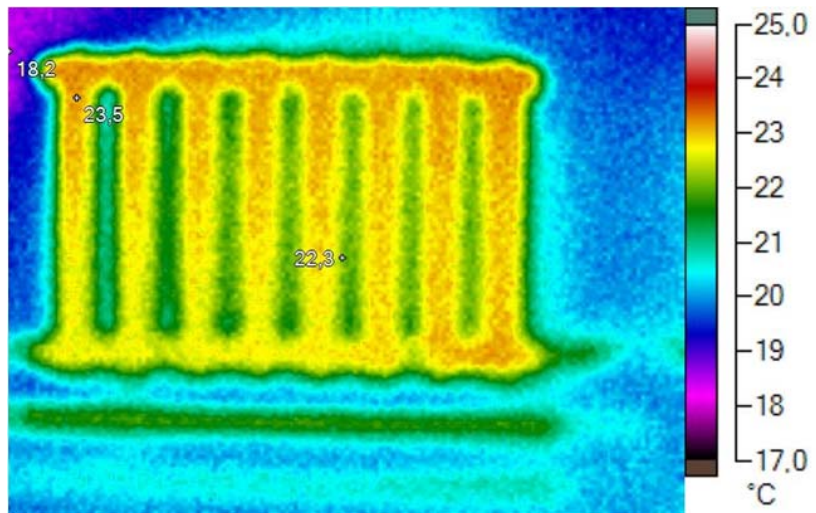

$a$

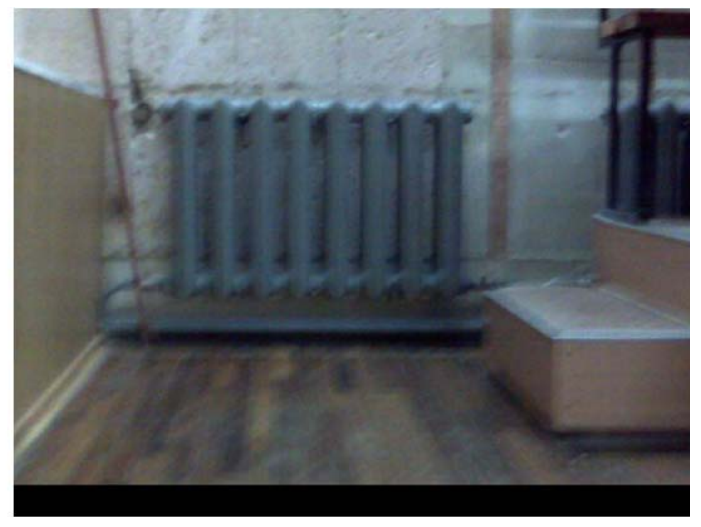

$b$

Fig. 8. Results of the examination of the heating system of the premises by a thermal imager:

$a$ - thermogram of the examination of the heating radiator IR004443.IS2; $b$ - visible-light image of the heating radiator

According to the radiator connection circuit, which is shown in Fig. 8, the heat carrier is supplied from the bottom right and comes out from the bottom left. Thus, the lower radiator line should have the lowest hydraulic resistance and the heat carrier should be of the same temperature at this place. Given that the radiator design makes it possible to give off heat in a convective way, that is, when heated, the outer air moves from the bottom of the radiator to the top, the upper part of the radiator should have the highest overall temperature. This is seen in the thermographic image. Thus, it was established that the radiator between the second and third sections at the bottom is clogged, which prevents the heat carrier from being distributed from the bottom up. Thus, in order to increase the uniformity of heating of the radiator surface, and thereby increase its efficiency, it is necessary to wash it with a special solution that washes the litter from its section.

5. 4. Development of an algorithm for the implementation of energy-saving measures in general-purpose premises

Our research makes it possible to devise energy-saving measures. The third stage of the energy audit can be presented in the form of the algorithm, which is shown in Fig. 9.

Each enterprise can set the $\Delta T$ indicator to determine the list of energy-saving measures depending on financial capacity. The lower this indicator, the more money will be needed to spend on energy-saving measures.

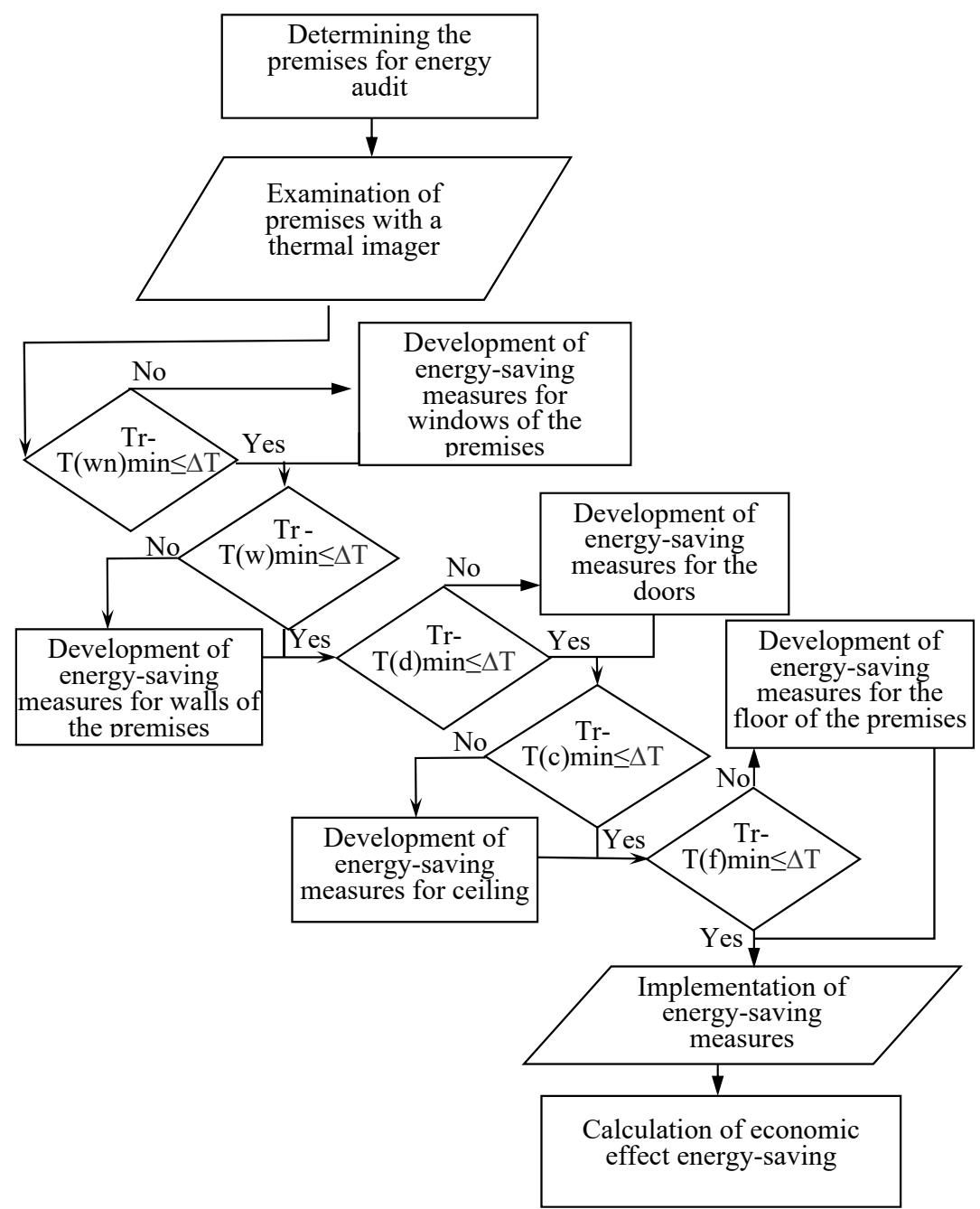

Fig. 9. Algorithm for the third stage of energy audit of the premises for general purposes: $\mathrm{Tr}$ - air temperature in the examined premises; $\mathrm{T}(\mathrm{wn}) \mathrm{min}-$ minimum temperature on the window surface in the premises; $T(w)$ min - minimum temperature on the wall surface of the premises; $T(d)$ min - minimum temperature on the door surface in premises; $\mathrm{T}(\mathrm{c}) \mathrm{min}$ - minimum temperature on the ceiling surface of the premises; $T(f) m i n$ - minimum temperature on the floor surface in the premises; $\Delta T-$ permissible deviation of the surface temperature from the indoor air temperature in the premises 
It is possible to state that a positive effect from the use of energy-saving measures is achieved based on the assessment of energy saving in quantitative and cost form. Comparison of current economic indicators of the activities of an educational institution before and after the implementation of energy-saving measures is determined from formula [26]:

$$
\begin{aligned}
& \Delta P_{t}=C f_{t} \cdot \Delta Q f_{t}+C h_{t} \cdot \Delta Q h_{t}+ \\
& +C e_{t} \cdot \Delta Q e_{t}+\Delta E_{t}-\left(C_{t}+n \cdot I_{t}\right)+\Delta Z_{t},
\end{aligned}
$$

where $C f_{t}$ is the price of saved conditional fuel at current tariffs within year $t$, c. u./t. c. f.;

$\Delta Q f_{t}$ is the decrease in the supply of conditional fuel to an enterprise within year $t$, t. c. f./year;

$C h_{t}$ is the tariff for purchasing heat energy within a year $t$, c. u./GJ;

$\Delta Q h_{t}$ is the decrease in heat consumption from outside within year $t$ due to implementation of measures on energy saving, GJ/year;

$C e_{t}$ is the tariff for electric energy obtained from the energy system within year $t$, c.u./kW-h;

$\Delta Q e_{t}$ is the decrease in consumption of electric energy from the energy system within year $t$ due to implementation of energy-saving measures, $\mathrm{kW}$-h/year;

$\Delta E_{t}$ is the decrease of payment of an enterprise for the environmental pollution within year $t$, which was due to the implementation of energy-effectiveness measures, c. u./year;

$C_{t}, I_{t}$ are the current costs and capital investment within year $t$, related to purchasing, installation, and operation of energy-saving equipment, c. u.;

$n$ is the internal norm of profitability;

$\Delta Z_{t}$ is the decrease of operating costs at an enterprise within year $t$, caused by the implementation of energy-saving measures, except for the costs of maintenance of energy-saving equipment, c.u./year.

Thus, the energy efficiency of the implementation of energy-saving measures $E_{j}$ can be calculated from the following formula:

$$
E_{j}=E\left(\frac{1}{1-\frac{\Delta P}{P}}\right),
$$

where $E$ is the original energy effectiveness.

Energy effectiveness after the implementation of an energy-saving measure is the summand of original energy efficiency by the coefficient depending on relative energy saving. This coefficient indicates by how many times the energy efficiency of the considered efficiency increases at relative energy saving equal to $\Delta P / P$.

\section{Discussion of the results of studying thermal losses in general-purpose premises and the proposed algorithm for their elimination}

The studies performed in the research prove the expediency of using the thermographic analysis of sources of thermal losses in premises.

Examination of the elements of the premises - windows, walls, ceilings, floors, doors, heating systems - with a special device Fluke Ti25 thermal imager makes it possible to identify the places that have increased heat losses. Additional analysis of such places allows determining the causes of energy losses and proposes the measures to reduce them.

The data on thermographic examination of the surfaces of the elements of buildings (Fig. 1-7) indicate significant heat losses. Temperature difference at the junctions of building structures relative to the temperature in the room varies in a significant range.

Thermographic scanning of the junctions of window blocks to the walls (Fig. 1) shows the temperature difference relative to the air temperature in the room equal to $6.5-13^{\circ} \mathrm{C}$. This temperature difference is explained by poor-quality installation work, window frames subsidence and the formation of gaps between the window and the wall, the failure of compactions between the elements of building structures, and the non-hermeticity of double-glazed windows.

Scanning the walls of the premises (Fig. 2) shows a difference in the temperature of the surface of the walls and air in the room of $2-7.3{ }^{\circ} \mathrm{C}$. First of all, this is due to the unsatisfactory heat transfer resistance of wall enclosures. In addition, some elements of the wall allow a leak of external moisture through the cracks, which leads to freezing and excessive cooling of the walls.

The resulting thermograms of the examination of the doors of the premises (Fig. 3, 4) show that the temperature of the surfaces of enclosures is by $3-4{ }^{\circ} \mathrm{C}$ less than that of the air in the room. This is due to the absence or failure of compactions between the doors and their frame. In addition, the studied windows and doors have been in operation for more than 30 years and do not meet the requirements of the current standards [42].

The obtained values of the temperature of the walls and junctions of building elements exceed the permissible value of the temperature difference by 1.6-3.3 times, which according to [41] for walls should not be more than $4{ }^{\circ} \mathrm{C}$.

Analysis of the thermograms of examination of the roof of the premises (Fig. 5,6) shows the difference of temperatures of the surfaces and that of internal air by $3.6-4.1{ }^{\circ} \mathrm{C}$. This is explained by a low value of heat transfer resistance of the ceiling. Additional analysis of the roof structure over the problem areas of the ceiling of the room indicated moisture leaking through the roof covering, which leads to its freezing.

The difference in temperature for the floor according to the thermogram (Fig. 7 ) is $3.7^{\circ} \mathrm{C}$. Such a sharp temperature difference indicates an unsatisfactory value of the heat transfer resistance of the floor and the loss of heat energy from the room to the basement, which is not heated.

Permissible values of temperature difference according to sanitary and hygienic requirements of regulatory documents are $3{ }^{\circ} \mathrm{C}$ for the ceiling and $2{ }^{\circ} \mathrm{C}$ for the floor, respectively [41]. The obtained results of the studies show an excess of normative values by 1.2-1.4 times for the ceiling and almost by 2 times for the floor.

Most premises of public institutions were built in the $70-80$ s of the last century. As practice shows, the heating systems of these premises are obsolete and need modernization. The conducted analysis of the heating system examination (Fig. 8) indicates a strong clogging of heat exchangers, which is explained by improper preparation of the heat carrier and obsolete equipment. In order to ensure uniform heating of radiator surfaces, and thereby increase their ef- 
ficiency, it is necessary to regularly wash radiator sections with special solutions.

For thermographic analysis of the premises of the building, an algorithm for conducting the third stage of energy audit was proposed. The developed algorithm (Fig. 9) makes it possible to systematize the process of energy audit of premises, break it into components, and, as a result, group energy-saving measures by elements of the building (windows, walls, roof, floor, doors).

The specific feature of this algorithm is that permissible deviation of surface temperature from the air temperature in room $\Delta T$ is used as the main audit parameter. Each enterprise can set the level of $\Delta T$ deviation to determine the list of energy-saving measures depending on its financial capacity.

The places with increased heat loss have a surface temperature much lower than the air temperature in the room. This research considered the places of heat losses, which have more than $10 \%$ of the temperature difference $\Delta T$ of the surface and air temperature in the room. This difference is used to obtain a significant economic effect.

The proposed algorithm can be used during the third stage of an energy audit for any premises of sizeable buildings, that is, a large number of premises. The algorithm makes it possible to group problem elements of premises (windows, walls, roof, floor, doors, heating systems) throughout the building. At the stage of removal of identified shortcomings, it is possible to use specialized teams of builders, which will affect the improvement of quality, reducing the costs and terms of these works.

The implementation of any energy-saving measures should be justified by the relevant economic calculations that make it possible to compare the activities of an enterprise before and after the implementation of energy-saving measures.

Internal defects of enclosing structures of premises during scanning by a thermal imager can be detected only in cases where they make changes in the temperature field on the surface of an object. This is the limitation of this study and there is a need for preliminary calculations and experiments. Thermal imaging examination can reveal a defect, the size, depth of location, and thermal characteristics of which create a change in the temperature field on the surface of an object, which is equal to the temperature sensitivity of the device.

A further direction of work is to determine thermal losses of premises through ventilation emissions and study the options for their disposal through the use of recuperative systems.

\section{Conclusions}

1. The conducted examination of the windows of the premises revealed the causes and places of heat energy losses. It was established that the temperature difference between the surface of the elements in the junction of windows with the walls and the ceiling is $17-45 \%$.

2 . The places and causes of heat energy losses through the walls and doors of the premises were determined. It was established that the temperature of the surface of problem areas is $10-21 \%$ lower than the air temperature in the rooms.

3. The places and causes of heat energy losses through the ceiling and the floor of the premises were determined. The results of the examination show that in characteristic places of heat losses, the surface temperature of the elements is $10-18 \%$ lower than the air temperature in the room. Thermographic analysis of the heating system was performed and the measures to increase its efficiency were proposed.

4. We proposed the algorithm for conducting the third stage of energy audit of premises, which makes it possible to systematize this process, break it down into components, and, as a result, group energy-saving measures into elements of the building, which will affect the improvement of the quality of work, reducing the cost and timing of their implementation. The algorithm can be used during the third stage of an energy audit for any buildings where the normative sanitary and hygienic requirements were not met. Such buildings are rather sizeable, in other words, they have a large number of rooms.

\section{References}

1. Nota, G., Nota, F. D., Peluso, D., Toro Lazo, A. (2020). Energy Efficiency in Industry 4.0: The Case of Batch Production Processes. Sustainability, 12 (16), 6631. doi: https://doi.org/10.3390/su12166631

2. Asphaug, S. K., Jelle, B. P., Gullbrekken, L., Uvsløkk, S. (2016). Accelerated ageing and durability of double-glazed sealed insulating window panes and impact on heating demand in buildings. Energy and Buildings, 116, 395-402. doi: https://doi.org/10.1016/ j.enbuild.2016.01.015

3. Ascione, F., Bianco, N., De Masi, R. F., de’ Rossi, F., Vanoli, G. P. (2015). Energy retrofit of an educational building in the ancient center of Benevento. Feasibility study of energy savings and respect of the historical value. Energy and Buildings, 95, 172-183. doi: https://doi.org/10.1016/j.enbuild.2014.10.072

4. Ciampi, G., Rosato, A., Scorpio, M., Sibilio, S. (2015). Retrofitting Solutions for Energy Saving in a Historical Building Lighting System. Energy Procedia, 78, 2669-2674. doi: https://doi.org/10.1016/j.egypro.2015.11.343

5. Litti, G., Khoshdel, S., Audenaert, A., Braet, J. (2015). Hygrothermal performance evaluation of traditional brick masonry in historic buildings. Energy and Buildings, 105, 393-411. doi: https://doi.org/10.1016/j.enbuild.2015.07.049

6. Mahajan, G., Cho, H., Shanley, K., Kang, D. (2015). Comprehensive modeling of airflow rate through automatic doors for low-rise buildings. Building and Environment, 87, 72-81. doi: https://doi.org/10.1016/j.buildenv.2015.01.016

7. Zahorulko, A., Zagorulko, A., Yancheva, M., Serik, M., Sabadash, S., Savchenko-Pererva, M. (2019). Development of the plant for low-temperature treatment of meat products using ir-radiation. Eastern-European Journal of Enterprise Technologies, 1 (11 (97)), 17-22. doi: https://doi.org/10.15587/1729-4061.2019.154950

8. Kasabova, K., Sabadash, S., Mohutova, V., Volokh, V., Poliakov, A., Lazarieva, T. et. al. (2020). Improvement of a scraper heat exchanger for pre-heating plant-based raw materials before concentration. Eastern-European Journal of Enterprise Technologies, 3 (11 (105)), 6-12. doi: https://doi.org/10.15587/1729-4061.2020.202501 
9. Radchuk, O. V., Savchenko-Pererva, M. Yu., Katcov, V. M. (2018). Ways to improve energy conservation by conducting energy audits. Visnyk Sumskoho natsionalnoho ahrarnoho universytetu, 10 (34), 73-77.

10. Nemish, P. D. (2013). Sutnist, otsinka ta napriamy pidvyshchennia efektyvnosti mekhanizmu enerhozberezhennia ahropromyslovoho kompleksu. Innovatsiyna ekonomika, 7 (45), 46-53.

11. Kostyuchenko, N., Petrushenko, Y., Smolennikov, D., Danko, Y. (2015). Community-based approach to local development as a basis for sustainable agriculture: experience from Ukraine. International Journal of Agricultural Resources, Governance and Ecology, 11 (2), 178-189. doi: https://doi.org/10.1504/ijarge.2015.072901

12. Savchenko-Pererva, M., Yakuba, A. (2015). Improving the efficiency of the apparatus with counter swirling flows for the food industry. Eastern-European Journal of Enterprise Technologies, 3 (10 (75)), 43-48. doi: https://doi.org/10.15587/ 1729-4061.2015.43785

13. Sukmanov, V. O., Radchuk, O. V., Savchenko-Pererva, M. Y., Budnik, N. V. (2020). Optical piezometer and precision researches of food properties at pressures from 0 to $1000 \mathrm{MPa}$. Journal of Chemistry and Technologies, 28 (1), 68-87. doi: https:// doi.org/10.15421/082009

14. Kasianova, N. (2017). Implementation of energy savings strategy for industrial enterprises. Efektyvna ekonomika, 2. Available at: http://www.economy.nayka.com.ua/?op=1\&z=5916

15. Ippolitova, I. Ya., Sorokotiazhenko, K. S. (2015). Formation of organizational and economic mechanism of energy saving in the enterprise. Hlobalni ta natsionalni ekonomichni problemy, 8, 406-411. Available at: http://global-national.in.ua/archive/8-2015/85.pdf

16. Krarti, M. (2020). Energy audit of building systems: An engineering approach. CRC Press, 658. doi: https:// doi.org/10.1201/9781003011613

17. Kontokosta, C. E., Spiegel-Feld, D., Papadopoulos, S. (2020). The impact of mandatory energy audits on building energy use. Nature Energy, 5 (4), 309-316. doi: https://doi.org/10.1038/s41560-020-0589-6

18. Tanic, M., Stankovic, D., Nikolic, V., Nikolic, M., Kostic, D., Milojkovic, A. et. al. (2015). Reducing Energy Consumption by Optimizing Thermal Losses and Measures of Energy Recovery in Preschools. Procedia Engineering, 117, 919-932. doi: https:// doi.org/10.1016/j.proeng.2015.08.179

19. Hee, W. J., Alghoul, M. A., Bakhtyar, B., Elayeb, O., Shameri, M. A., Alrubaih, M. S., Sopian, K. (2015). The role of window glazing on daylighting and energy saving in buildings. Renewable and Sustainable Energy Reviews, 42, 323-343. doi: https:// doi.org/10.1016/j.rser.2014.09.020

20. Thomsen, K. E., Rose, J., Mørck, O., Jensen, S. Ø., Østergaard, I., Knudsen, H. N., Bergsøe, N. C. (2016). Energy consumption and indoor climate in a residential building before and after comprehensive energy retrofitting. Energy and Buildings, 123, 8-16. doi: https://doi.org/10.1016/j.enbuild.2016.04.049

21. Cheng, Z. (2017). China's Wisdom to Promote World Energy Transformation and Development. Wisdom China, 07, 10-12.

22. Zagorec, M., Josipovic, D., Majer, J. (2008). Measures for saving thermal energy in buildings. Gradevinar, 60 (5), 411-420. Available at: http://casopis-gradjevinar.hr/assets/Uploads/JCE-60-2008-05-03.pdf

23. Kirimtat, A., Krejcar, O. (2018). A review of infrared thermography for the investigation of building envelopes: Advances and prospects. Energy and Buildings, 176, 390-406. doi: https://doi.org/10.1016/j.enbuild.2018.07.052

24. Ferrarini, G., Bison, P., Bortolin, A., Cadelano, G. (2016). Thermal response measurement of building insulating materials by infrared thermography. Energy and Buildings, 133, 559-564. doi: https://doi.org/10.1016/j.enbuild.2016.10.024

25. Heiets, V. M. (2016). Rozvytok ta vzaiemodiya ekonomichnoi ta enerhetychnoi polityky v Ukraini (stenohrama naukovoi dopovidi na zasidanni Prezydiyi NAN Ukrainy 16 hrudnia 2015 r.). Visnyk Natsionalnoi akademiyi nauk Ukrainy, 2, 46-53. Available at: http://nbuv.gov.ua/UJRN/vnanu_2016_2_10

26. Inshekov, Ye. M., Nikitin, Ye. Ye., Tarnovskyi, M. V., Cherniavskyi, A. V. (2014). Posibnyk z munitsypalnoho enerhetychnoho menedzhmentu. Kyiv: Polihraf plius, 238. Available at: https://merp.org.ua/images/Docs/Handbook_EM.pdf

27. Sabadash, S., Savchenko-Pererva, M., Radchuk, O., Rozhkova, L., Zahorulko, A. (2020). Improvement of equipment in order to intensify the process of drying dispersed food products. Eastern-European Journal of Enterprise Technologies, 1 (11 (103)), 15-21. doi: https://doi.org/10.15587/1729-4061.2020.192363

28. Savoiskyi, O., Yakovliev, V., Sirenko, V. (2021). Determining the kinetic and energy parameters for a combined technique of drying apple raw materials using direct electric heating. Eastern-European Journal of Enterprise Technologies, 1 (11 (109)), 33-41. doi: https://doi.org/10.15587/1729-4061.2021.224993

29. Pro enerhetychnu efektyvnist: Zakon Ukrainy No. 1818-IX vid 21.10.2021. Available at: http://www.golos.com.ua/article/353308

30. DSTU 4065-2001. Energy saving. Energy audit. General technical requirements (ANSI/IEEE 739:1995, NEQ). Kyiv: Derzhstandart Ukrainy, 38. Available at: http://online.budstandart.com/ua/catalog/doc-page.html?id_doc=68875

31. ISO50002:2014. Energyaudits - Requirements withguidancefor use.Availableat:https://www.iso.org/obp/ui/\#iso:std:iso:50002:ed1:v1:en

32. Pro zatverdzhennia Typovoi metodyky "Zahalni vymohy do orhanizatsiyi ta provedennia enerhetychnoho audytu". Nakaz Natsionalnoho ahentstva Ukrainy z pytan zabezpechennia efektyvnoho vykorystannia enerhetychnykh resursiv No. 56 vid 20.05.2010. Available at: https://zakon.rada.gov.ua/rada/show/v0056656-10\#Text

33. Moynihan, G. P., Barringer, F. L. (2017). Energy Efficiency in Manufacturing Facilities: Assessment, Analysis and Implementation. Energy Efficient Buildings. doi: https://doi.org/10.5772/64902 
34. Cho, H. M., Yun, B. Y., Yang, S., Wi, S., Chang, S. J., Kim, S. (2020). Optimal energy retrofit plan for conservation and sustainable use of historic campus building: Case of cultural property building. Applied Energy, 275, 115313. doi: https://doi.org/10.1016/ j.apenergy.2020.115313

35. Ascione, F., Cheche, N., Masi, R. F. D., Minichiello, F., Vanoli, G. P. (2015). Design the refurbishment of historic buildings with the cost-optimal methodology: The case study of a XV century Italian building. Energy and Buildings, 99, 162-176. doi: https:// doi.org/10.1016/j.enbuild.2015.04.027

36. Iychettira, K. K., Hakvoort, R. A., Linares, P., de Jeu, R. (2017). Towards a comprehensive policy for electricity from renewable energy: Designing for social welfare. Applied Energy, 187, 228-242. doi: https://doi.org/10.1016/j.apenergy.2016.11.035

37. Kumar, J. C. R., Majid, M. A. (2020). Renewable energy for sustainable development in India: current status, future prospects, challenges, employment, and investment opportunities. Energy, Sustainability and Society, 10 (1). doi: https://doi.org/10.1186/ s13705-019-0232-1

38. Savchenko-Pererva, M., Radchuk, O. (2020). Implementation of energy saving measures in the university building. International Sustainable Development Conference 2020. Pingtung, 105-106. Available at: http://repo.snau.edu.ua/ bitstream/123456789/8491/1/2.pdf

39. DSTU B EN 13187:2011. Teplovi kharakterystyky budivel. Yakisne vyiavlennia teplovykh vidmov v ohorodzhuvalnykh konstruktsiyakh. Infrachervonyi metod (EN 13187:1998, IDT) (2012). Kyiv: Minrehionbud Ukrainy, 33. Available at: http:// odz.gov.ua/lean_pro/normdocs/files/DSTU_B_\%D0\%95N_13187-2011.pdf

40. EN 13187:1998. Thermal performance of buildings - Qualitative detection of thermal irregularities in building envelopes - Infrared method (ISO 6781:1983 modified). Available at: https://standards.iteh.ai/catalog/standards/cen/22492a43-9c5a-4ddc-ba20df0226b4148d/en-13187-1998

41. DBN V.2.6-31:2016. Thermal insulation of buildings (2017). Kyiv: Minrehionbud Ukrainy, 30. Available at: https://dbn.co.ua/dbn/ DBN_V.2.6-31-2016_Teplova_izolyatsiya_budively.pdf

42. DSTU B V.2.6-23:2009. Construction of buildings and structures. Windows and doors. General specification (2009). Kyiv: Minrehionbud Ukrainy, 32. Available at: http://ksv.do.am/GOST/DSTY_ALL/DSTY4/dstu_b_v.2.6-23-2009.PD 